\title{
Description of the larva of Oecetis mizrain Malicky \& Graf, 2012 (Trichoptera, Leptoceridae) and Lepidostoma scotti (Ulmer, 1930) (Trichoptera, Lepidostomatidae) from Chilimo Forest, Central Ethiopia
}

\author{
Yonas Terefe ${ }^{1,2}$, Simon Vitecek ${ }^{3,4}$, Wolfram Graf ${ }^{1}$ \\ I Institute of Hydrobiology and Aquatic Ecology Management, University of Natural Resources and Applied \\ Life Sciences, Vienna, Austria 2 Department of Biology, College of Natural and Computational Sciences, Ambo \\ University, Ambo, Ethiopia 3 Department for Limnology \& Bio-Oceanography, University of Vienna, Vienna, \\ Austria 4 Senckenberg Research Institute and Natural History Museum, Frankfurt am Main, Germany \\ Corresponding author: Yonas Terefe (yonasterefe56@gmail.com)
}

Academic editor: R. Holzenthal | Received 8 March 2018 | Accepted 22 May 2018 | Published 13 June 2018

http://zoobank.org/3ABCCBB1-0C7B-4BE6-92DF-8E067C50E6AF

Citation: Terefe Y, Vitecek S, Graf W (2018) Description of the larva of Oecetis mizrain Malicky \& Graf, 2012 (Trichoptera, Leptoceridae) and Lepidostoma scotti (Ulmer, 1930) (Trichoptera, Lepidostomatidae) from Chilimo Forest, Central Ethiopia. ZooKeys 766: 63-77. https://doi.org/10.3897/zookeys.766.24544

\begin{abstract}
The Ethiopian caddisfly fauna comprises 85 species, including 10 Oecetis species and three Lepidostoma species. In this context we provide the first species-level descriptions of Ethiopian caddisfly larvae. We describe and illustrate the larvae of $O$. mizrain and $L$. scotti, with additional notes on their habitats and distribution.
\end{abstract}

\section{Keywords}

caddisfly larvae, distribution, ecology, Afrotropical Region, diversity, ecological management

\section{Introduction}

Caddisflies are one of the most diverse aquatic insect groups, distributed all over the world. The order Trichoptera comprises approximately 15,000 species (including 685 fossils) in 616 genera and 49 families (Morse 2017). The Oriental region

Copyright Yonas Terefe et al. This is an open access article distributed under the terms of the Creative Commons Attribution License (CC BY 4.0), which permits unrestricted use, distribution, and reproduction in any medium, provided the original author and source are credited. 
harbors the highest number of species (4865 species), followed by the Neotropical region (2562 species) (de Moor and Ivanov 2008; Holzenthal et al. 2015; Morse 2011). Species numbers in other biogeographic regions such as the Australasian (1439 species), the East Palearctic (1372 species), the Nearctic (1604 species) and the West Palearctic (1888 species) are lower in comparison (Morse 2011). The poorly explored Afrotropical region is currently represented by about 1200 species only, belonging to 28 families and 111 genera (Tobias and Tobias 2008). The Antarctic region is the only biogeographic area where no caddisflies have been recorded (Holzenthal et al. 2015; Morse 2011).

As in many Afrotropical countries, the Ethiopian caddisfly fauna is poorly studied. In a first effort to characterize the almost unknown African caddisfly fauna, Ulmer (1930) described and listed eight Ethiopian Trichoptera species. Three decades later, Kimmins (1963) reported 51 species, of which 17 were described as new. At present, the number has marginally increased to 85 species of 26 genera and nine families (Tobias and Tobias 2008; Morse 2017). Two families, Leptoceridae (35 species in 10 genera) and Hydropsychidae (22 species in six genera), represent over $60 \%$ of the currently known Ethiopian Trichoptera diversity.

Caddisflies of the widely distributed genera Lepidostoma Rambur, 1842 and Oecetis Mclachlan, 1877 comprise 453 and 539 extant species worldwide, respectively (Morse 2017). From Africa and its adjacent islands, 51 Lepidostoma and 103 Oecetis species are known (Tobias and Tobias 2008). The Checklist of East Africa (Johanson 1992) includes two Lepidostoma and 17 Oecetis species. Until now, three Lepidostoma and 10 Oecetis species have been recorded in Ethiopia (Table 1).

Within the genus Lepidostoma, the first species described from Ethiopia was $L$. scotti (Ulmer, 1930). Ulmer (1930) described the species based on the material obtained by Hugh Scott and Omur-Cooper during their expedition to the central highlands of Ethiopia. Since then, only two additional species have been described from Ethiopia, L. missa and L. zepho (Malicky \& Graf, 2012). In the genus Oecetis, the species described first from Ethiopia was O. montana (Ulmer, 1930), based on specimens collected in the central highlands. Later, Kimmins (1963) described O. tjonnelandi, O. ghibensis, O. brevis and indicated the presence of O. brunnescens (Ulmer, 1923), O. montana (Ulmer, 1930), O. pangana Navás, 1930 and O. setifera (Ulmer, 1922) in Ethiopia. Most recently, Malicky and Graf $(2012,2015)$ described $O$. armaros Malicky \& Graf, 2015, O. mizrain Malicky \& Graf, 2012 and reported O. portalensis Mosely, 1939 from rivers in the Ethiopian highlands.

Caddisflies are frequently used along with other aquatic fauna as bioindicators in ecological assessment systems as they are sensitive to organic pollution and stream degradation (Barbour et al. 1999). In particular autecological characterization provides vital information for freshwater bioassessment by relating species to ecological conditions (Jones 2008). In this context, species-level identification of bioindicators is of great importance to fully reap the power of ecological analysis (Cranston 1990; Lenat and Resh 2001; Malicky et al. 2008). Species-level determination is achieved for Trichoptera and many other taxonomic groups in Central and Northern European 
Table I. Species of Lepidostoma and Oecetis occurring in Ethiopia following Kimmins (1963) and Malicky and Graf (2012, 2015); ecoregions according to Abell et al. (2008); distribution status from Tobias and Tobias (2008). AT, Afrotropical; EH, Ethiopian Highlands; LT, Lake Turkana; NER, Northern Eastern Rift; ${ }^{* *}$, not reported outside of Ethiopia.

\begin{tabular}{|c|c|c|}
\hline Taxa & Biogeographic region, Ecoregions (areas) & $\begin{array}{c}\text { Distribution } \\
\text { in Africa }\end{array}$ \\
\hline \multicolumn{3}{|l|}{ Genus Lepidostoma Rambur, 1842} \\
\hline L. missa Malicky \& Graf, 2012 & AT, EH (Semien Mts., Chenek pass) & $* *$ \\
\hline L. scotti (Ulmer, 1930) & $\begin{array}{l}\text { AT, EH (Leliso River, Small stream north of } \\
\text { Addis Ababa), LT (Gughe Mt.) }\end{array}$ & $* *$ \\
\hline L. zepho Malicky \& Graf, 2012 & AT, EH (Leliso River) & ** \\
\hline \multicolumn{3}{|l|}{ Genus Oecetis Mclachlan, 1877} \\
\hline O. armaros Malicky \& Graf, 2015 & AT, EH (Small stream N from Addis Ababa) & ** \\
\hline O. brevis Kimmins, 1963 & AT, LT (Gibe River) & Ghana \\
\hline O. brunnescens (Ulmer, 1923) & AT, NER (Lake Awassa) & Sudan \\
\hline O. ghibensis Kimmins, 1963 & $\begin{array}{l}\text { AT, LT (Gibe River), NER (Koka Dam, } \\
\text { Sodere) }\end{array}$ & $* *$ \\
\hline O. mizrain Malicky \& Graf, 2012 & AT, EH (Leliso River \& Meribo River) & ** \\
\hline O. montana Ulmer, 1930 & AT, EH (Central Highlands) & ** \\
\hline O. pangana Navás, 1930 & AT, NER (Koka Dam, Gibe River) & $\begin{array}{c}\text { Senegal, Ghana, } \\
\text { D.R. Congo }\end{array}$ \\
\hline O. portalensis Mosely, 1939 & AT, EH (Leliso River, Meribo River) & Uganda \\
\hline O. setifera Ulmer, 1922 & AT, LT (Lake Awassa, Lake Abaya) & $\begin{array}{c}\text { Sudan, D.R. Congo, } \\
\text { Malawi, Namibia }\end{array}$ \\
\hline O. tjonnelandi Kimmins, 1963 & AT, LT (Gibe River) & Namibia \\
\hline
\end{tabular}

countries where this information is used for stream quality assessments (Hering et al. 2003; Schmidt-Kloiber et al. 2006). Most studies in tropical Africa including Ethiopia, however, are restricted to family-level identification due to the lack of taxonomic knowledge (Aschalew and Moog 2015). Therefore, to support efforts to maintain the general ecological health of fresh waters and thus ensure sustainable use of water resources in Ethiopia the compilation of taxonomic and autecological databases for all potential bioindicators is essential. Hence, in this contribution, we describe and illustrate the final instar larvae of L. scotti and O. mizrain from Ethiopia.

\section{Material and methods}

Larval and adult material was collected at small highland streams $\left(9^{\circ} 4^{\prime} \mathrm{N}, 38^{\circ} 8^{\prime} \mathrm{E}\right)$ within Chilimo Forest, in the upper catchment of the Awash River. Association of larvae and adults was enabled by the exclusive occurrence of these Lepidostoma and Oecetis species at this site and the presence of mature pupae in the case of O. mizrain. Chilimo Forest is a dry afromontane forest, located about $97 \mathrm{~km}$ west of Addis Ababa and $7 \mathrm{~km}$ north of Ginchi town. It covers an area of more than 2500 hectares within 
an altitudinal range from $2170 \mathrm{~m}$ a.s.l. to $3054 \mathrm{~m}$ a.s.l. (Teshome and Ensermu 2013). The forest and its surrounding areas receive little precipitation from March to April, while precipitation is highest from June to September with a mean annual rainfall of $>1000 \mathrm{~mm}$ (Aschalew 2015). The dominant trees species in this forest are Juniperus procera, Podocarpus falcatus, Prunus africana, and Olea europaea (Kassa et al. 2009; Teshome and Ensermu 2013).

The collected larval specimens were preserved in 70\% ethyl alcohol. Morphological characteristics of specimens were examined and photographed using a Zeiss StereoLumar V.12 equipped with an AxioCamErc5s camera and the Zeiss-native image processing software ZEN. Image series at different focus levels were obtained and stacked via CombineZP (Hadley 2008; Brecko et al. 2014) to create single extended-depth-offocus images. Larval morphological features and nomenclature of primary setae and setal areas follows Wiggins (1996) and Waringer and Graf (2011).

\section{Results}

\section{Order Trichoptera \\ Family Leptoceridae}

\section{Oecetis mizrain Malicky \& Graf, 2012}

Figs $1-12$

Material. 8 larvae: Ethiopia, Oromia Region, Chilimo forest $\mathrm{N}$ of Ginchi, $2451 \mathrm{~m}$ a.s.l., $9.059719^{\circ} \mathrm{N}, 38.14332^{\circ} \mathrm{E} ; 20 . i i .2016$; leg. \& det. W. Graf; specimens deposited in the research collection of W. Graf at the University of Natural Resources and Applied Life Sciences Vienna [contact: wolfram.graf@boku.ac.at] and the Senckenberg Research Institute and Natural History Museum Trichoptera collection [collection number SMFTRI00018576; contact: Steffen U. Pauls - steffen.pauls@senckenberg.de].

Description of the $5^{\text {th }}$ instar larva. Biometry. Larva eruciform, body length 4.5-5.0 mm, head width 0.69-0.78 mm ( $\mathrm{n}=4)$.

Head. Head capsule hypognathous, elongated, with smooth surface; head capsule distally slightly narrower. As in all final instar larvae of Leptoceridae, subocular ecdysial line present on parietalia, running from foramen occipitale to lateral section of parietalia, ventrally to eyes, at anterior region of eyes bending dorsally, meeting frontoclypeal suture (Fig. 2, black arrow). General color of head capsule pale to golden brown (Figs 2,3); posterodorsal margin whitish, ventral occipital margin whitish with palebrown line; ventral apotome brown with white corners; lateroventral sclerites defined by subocular ecdysial suture dorsally brown; parietalia and frontoclypeus around dorsal ecdysial line with distinct, pale muscle attachment spots; white ring around eyes, slightly wider than eye diameter. Head capsule with complete set of primary setae, and additional linear groups of setae around setae \#16 and 17. Frontoclypeus scutiform, without distinct medial constriction. Labrum light brown, with setal brush and all 


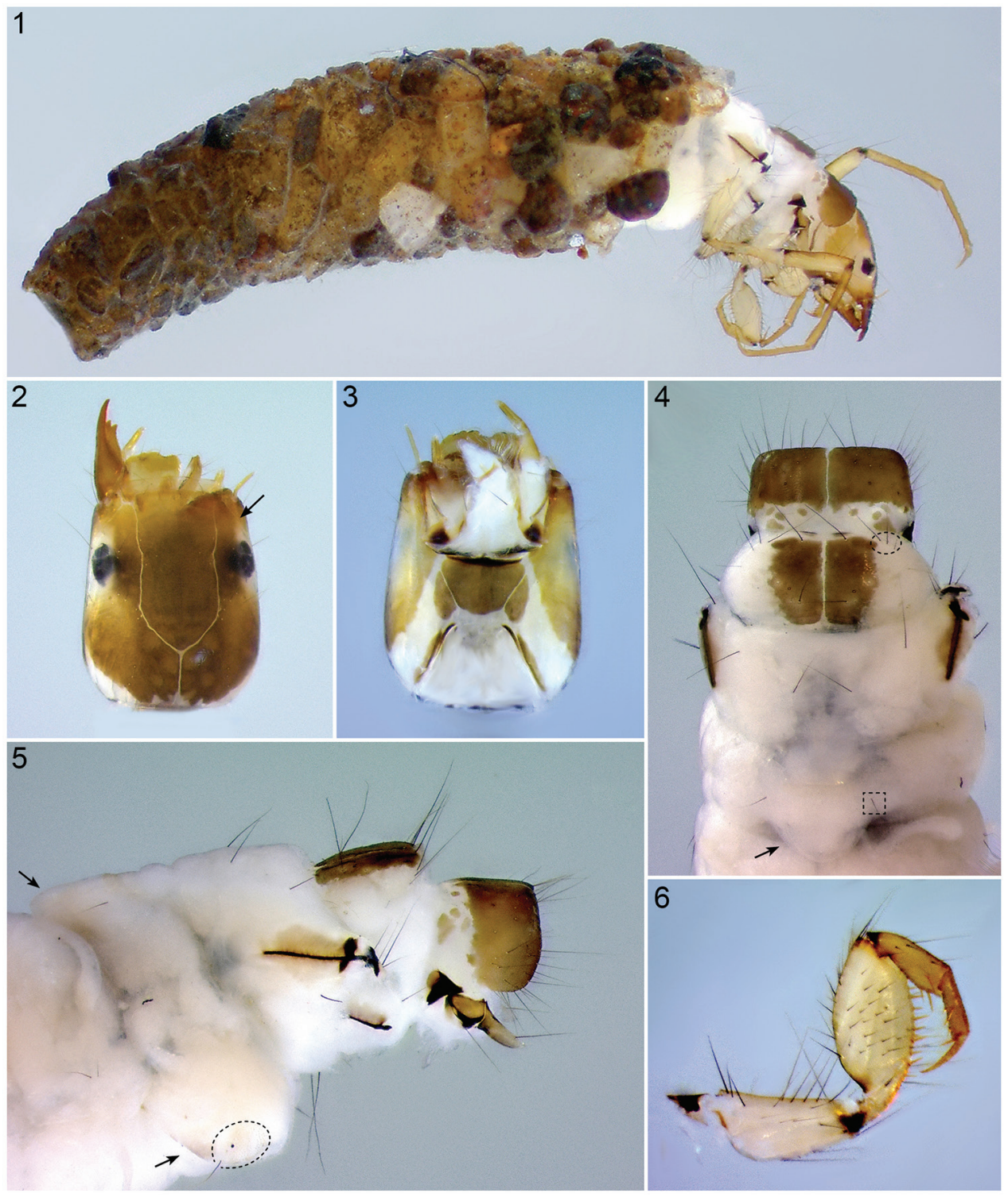

Figures I-6. Oecetis mizrain, $5^{\text {th }}$ instar larva. I Larva with the case, $14 \times \mathbf{2}$ Head, dorsal view (arrow indicates subocular ecdysial line), 50× 3 Head, ventral view, 65× 4 Thorax (Pro-, Meso- and Metanotum) and abdominal segment $\mathrm{I}$, dorsal view (dashed oval indicates mesonotal $s a_{3}$, dashed square indicates adominal segment I $s a_{2}$, arrow indicates abdominal segment I dorsal protuberance), $45 \times \mathbf{5}$ Thorax and abdominal segment I, lateral view (arrows indicate abdominal segment I dorsal and lateral protuberances, dashed outline indicates abdominal segment I lateral sclerite), $45 \times 6$ Left front leg, anterior face, $80 \times$.

primary setae. Mandible slender, elongate, with single cutting edge and 3 teeth. Ventral apotome isosceles trapezoidal, rounded corners. Antennae near distal parietal border (Fig. 2), long (more than $6 \times$ longer than wide) and with single terminal seta (Fig. 2). 

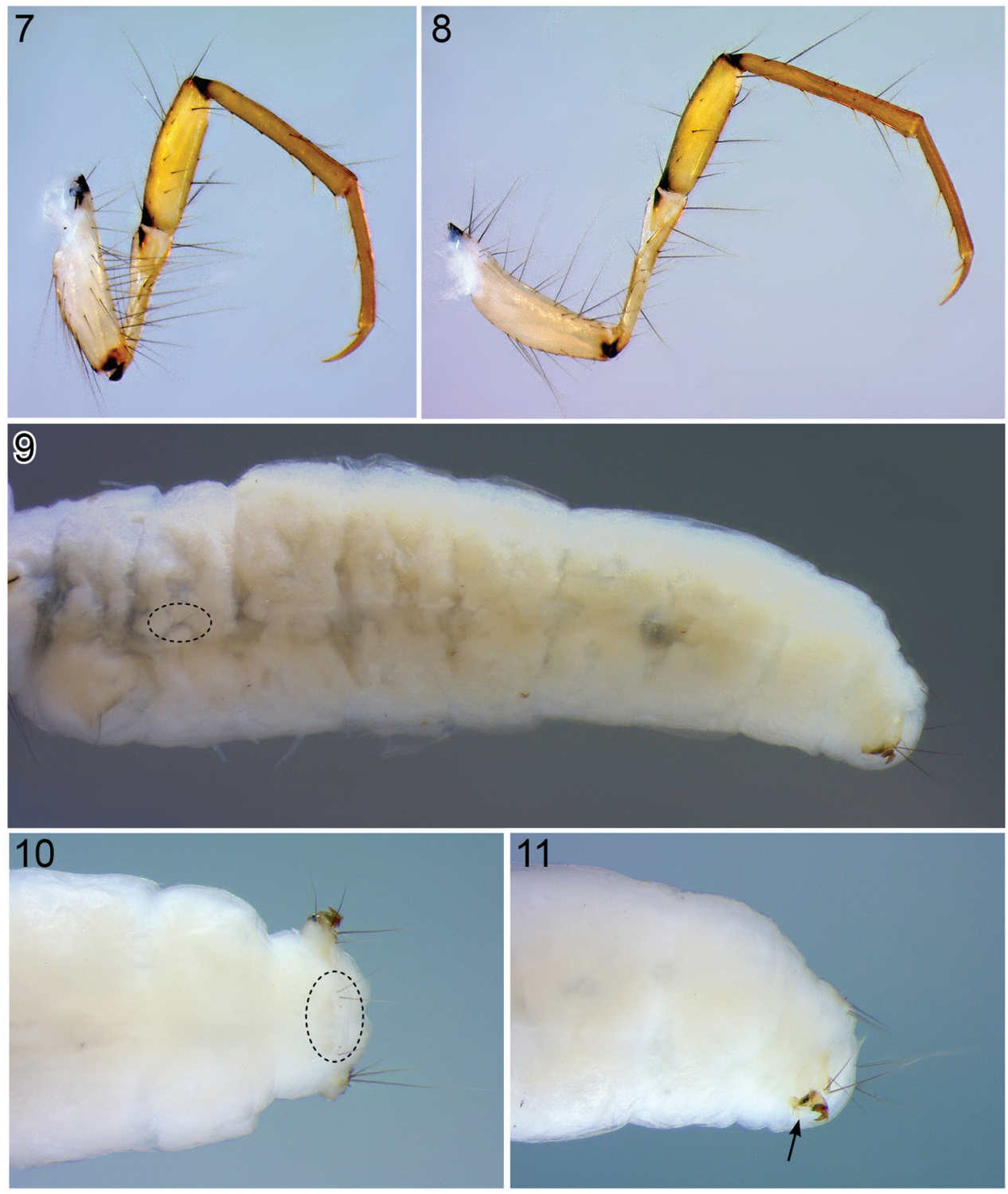

Figures 7-I I. Oecetis mizrain, $5^{\text {th }}$ instar larva. 7 Left middle leg, anterior face, $50 \times 8$ Left hind leg, anterior face, $60 \times 9$ Abdominal segment I-X, lateral view, $25 \times 10$ Abdominal segment IX, dorsal view (dashed oval indicates abdominal segment IX tergite), 50× II Anal proleg, lateral view, 50× (arrow indicates section of anal proleg where prominent spines or tines may be present in other Leptoceridae).

Thorax. Prothorax fully covered by 2 large sclerites, light brown to brown; small fragments of sclerites present posterior to each pronotal half (Fig. 4). Including anterior setal rows, 25-28 setae of varying lengths distributed over each pronotal half (Figs 4, 5). Mesonotum with 2 large sclerites covering about $50 \%$ of its area while not reaching 


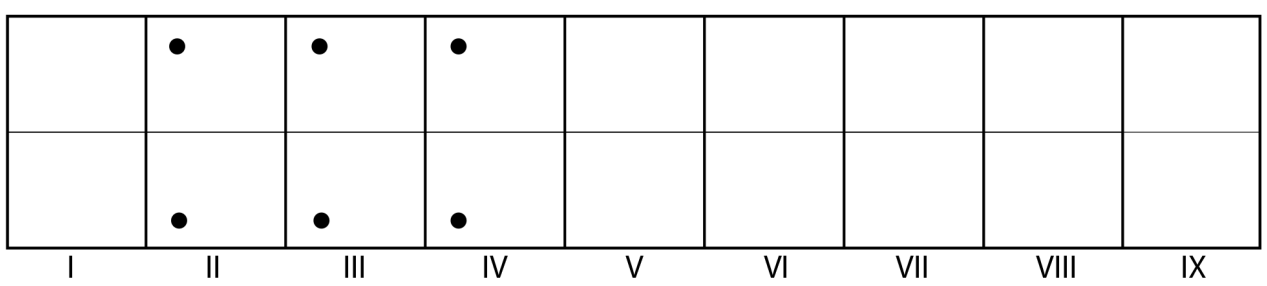

Figure 12. Oecetis mizrain, $5^{\text {th }}$ instar larva. Gill diagram indicating position of dorsal and ventral abdominal gills; lateral gills absent. Lateral line seemingly absent.

lateral margins, each with small anterior sclerite. Including anterior setal rows, 3-4 setae distributed over each mesonotal half; setae of setal area $3\left(s a_{3}\right)$ on the unsclerotized part of each mesonotal half (Fig. 4; dashed oval). Metanotum completely unsclerotized; metanotal setal areas $s a_{2}$ and $s a_{3}$ each with single seta only; setal area $s a_{1}$ not developed (Fig. 4). Metasternum with transverse band of setae on either side, each comprising 2-3 setae (Fig. 5). Legs yellowish beige, with numerous setae (Figs 6-8); foreleg with numerous stout setae on anterior face of femur and with row of stout yellow setae along ventral edge of femur (Fig. 6); foretrochantin with single seta (Fig. 6); tarsal claw of mid leg curved (Fig. 7); hind leg much longer than mid leg, as typical for this genus (Fig. 8).

Abdomen. Abdomen white, cylindrical (Fig. 9). Abdominal segment I with 3 protuberances (Figs 4, 5; arrows); dorsal setal areas $s a_{1}$ and $s a_{3}$ not developed, dorsal setal area $s a_{2}$ with single seta on either side (Fig. 4, dashed square); lateral sclerite weakly sclerotized, mostly translucent, oval, with 1 seta (Fig. 5, dashed outline). Abdominal tergum IX with weakly sclerotized, mostly translucent sclerite, bearing 6 long setae in 2 groups concentrated laterally (Fig. 10, dashed oval). Anal proleg weakly sclerotized, each with large lateral sclerite and more strongly sclerotized anal claw and little accessory hook; each bearing several long setae; spines or tines on anal prolegs absent (Fig. 11, arrow). Lateral line not visible, a group of setae (2-3) present laterally on abdominal segment II (Fig. 9, dashed oval); dorsal gills only present at anterolateral position on segments II-IV, lateral gills absent, ventral gills only present at anterolateral position on segments II-IV (Fig. 12).

Case. Length 4.9-5.3 mm. Case of final instar larvae constructed of small sand grains, tusk-shaped; anterior opening with overhanging dorsal portion, posterior opening closed with silk (Fig. 1).

\section{Family Lepidostomatidae}

\section{Lepidostoma scotti Ulmer, 1930}

Figs $13-25$

Material. 12 larvae: Ethiopia, Oromia Region, Chilimo forest $\mathrm{N}$ of Ginchi, $2451 \mathrm{~m}$ a.s.1., $9.059719^{\circ} \mathrm{N}, 38.14332^{\circ} \mathrm{E}$; 20.ii.2016; leg. \& det. W. Graf; specimens deposited 


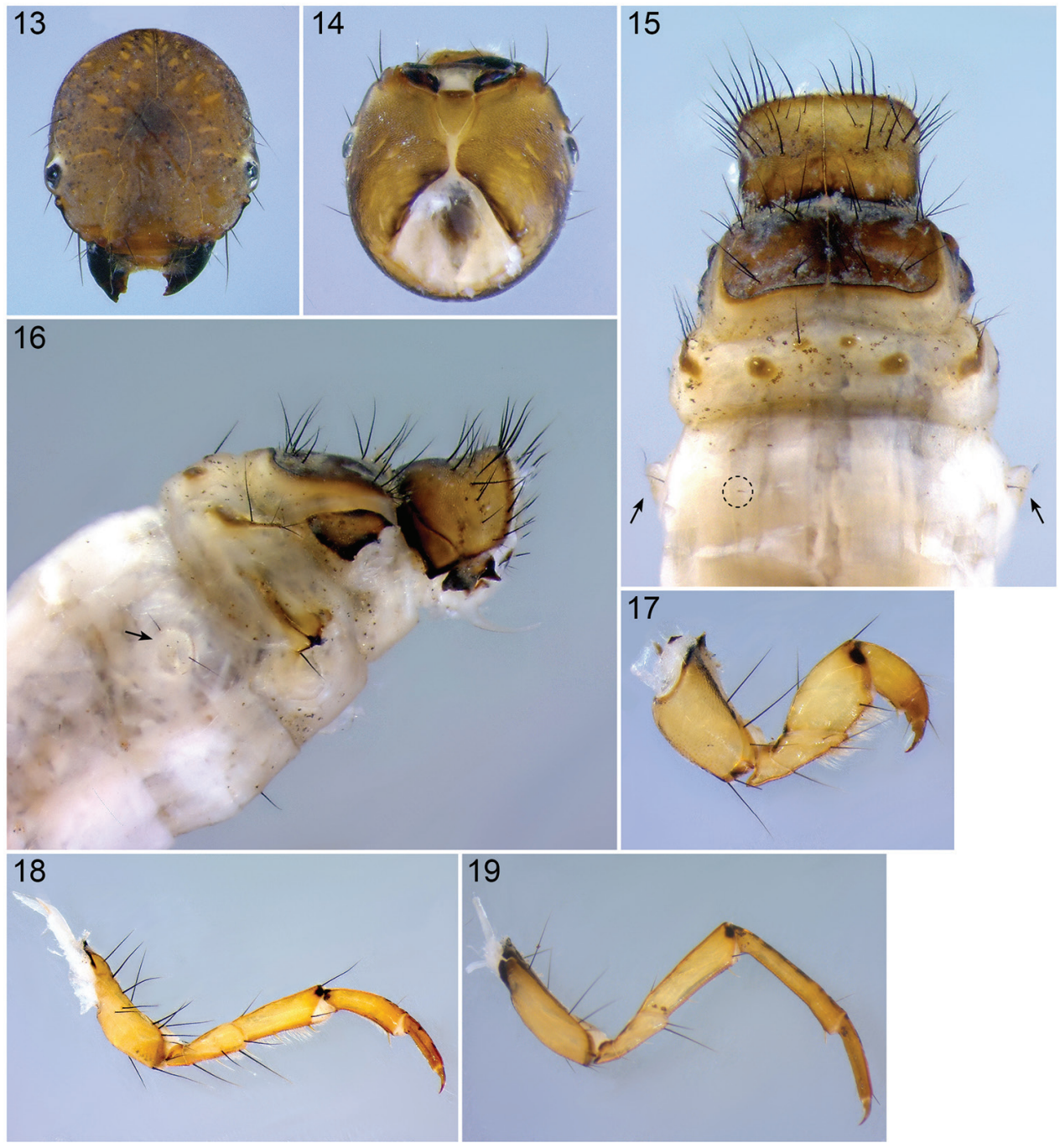

Figures 13-19. Lepidostoma scotti, $5^{\text {th }}$ instar larva. 13 Head, dorsal view, $40 \times 14$ Head, ventral view, 50x 15 Pro-, Meso- \& Metanotum and abdominal segment I, dorsal view (arrows indicate abdominal segment I lateral protuberances, dashed circle indicate abdominal segment I $\left.s a_{2}\right), 25 \times 16$ Thorax and abdominal segment I, lateral view (arrow indicates abdominal segment I lateral protuberance), $23 \times 17$ Left front leg, anterior face, 50× $18 \mathrm{Left}$ middle leg, anterior face, $40 \times 19$ Left hind leg, anterior face, 40×.

in the research collection of W. Graf at the University of Natural Resources and Applied Life Sciences Vienna [contact: wolfram.graf@boku.ac.at] and the Senckenberg Research Institute and Natural History Museum Trichoptera collection [collection number SMFTRI00018577; contact: Steffen U. Pauls - steffen.pauls@senckenberg.de].

Description of $5^{\text {th }}$ instar larva. Biometry. Larva eruciform, body length 8-9.5 $\mathrm{mm}$, head width $0.87-0.94 \mathrm{~mm}(\mathrm{n}=8)$. 
Head. Head capsule hypognathous, round; surface granulated, covered in spicules. Color pale to dark brown, with scattered black markings (Fig. 13), area around occipital margin dark brown (Figs 13, 14). Muscle attachment spots pale brown, $>10$ on each parietalia, slightly asymmetrical, lining in rows, absent on frontoclypeus. Complete set of 18 primary setae present; setae 4, 5, 13, 15 and 17 very lightly colored; short antenna situated near the anterior margin of each eye, positioned on discrete protuberance (Fig. 13). Whitish ring present around eyes. Frontoclypeus with central constriction; ventral apotome triangular, yellow-brown (Fig. 14). Labrum with 6 pairs of setae, labral brushes at anterior margin present. Mandible robust, black, with 3 teeth.

Thorax. Pronotum fully covered by 2 sclerites (Fig. 15), pale brown to brown, at posterior (with small lateral process) and posterolateral margins thickened and darkly lined (Fig. 15); each sclerite bears 20-25 long dark setae mostly concentrated in anterior half (including two rows of setae along anterior margin) (Figs 15, 16). Prosternal horn present, whitish, curved anteriorly (Fig. 16). Mesonotum fully covered by 2 sclerites, brown to dark brown (black near median suture), posterior margin with slightly sclerotized narrow dark line; mesonotal setal areas $s a_{1}, s a_{2}$ and $s a_{3}$ present; $s a_{1}$ bearing 3-4 setae; $s a_{2}$ bar-shaped, bearing 6-8 setae, stretching to posterior margin; $s a_{3}$ bearing 5-6 setae; $s a_{1}$ and $s a_{3}$ connected by regular bands of setae (Fig. 15). Metanotum with 6 distinct small sclerotized areas, corresponding to setal areas $s a_{1}, s a_{2}$ and $s a_{3} ; s a_{1}$ and $s a_{2}$ rounded, each with 1 and 1-2 setae respectively (Fig. 15); sa ${ }_{3}$ elongate, falcate shaped, bearing 4-6 setae (Figs 15, 16). Thoracic legs yellowish brown, with dark marking at femoro-tibial joint and with dense fringe of setae on ventral edge of coxa, trochanter and femur and long dark setae (Fig. 17); foreleg more robust, shorter than mid- and hind leg; mid leg bearing larger number of setae (majority at the coxa) than fore- and hind legs; tarsal claws similar in all legs, short, robust (Figs 17-19).

Abdomen. Color whitish (Figs 20, 21). Abdominal segment I with lateral humps bearing 2 setae (1 on anteroventral margin, 1 on dorsal margin) (Figs 15, 16, 20, 21; highlighted by arrows in Figs 15, 16); dorsal hump absent (Figs 15, 16, 20); dorsal setal areas $s a_{1}$ and $s a_{3}$ absent, $s a_{2}$ present, with a single seta (Fig. 15, dashed circles; Fig. 20); ventral setal areas $s a_{2}$ and $s a_{3}$ present, each with a single seta; $s a_{1}$ absent (Figs 16, 21). Tracheal gills simple, unbranched, as single filaments; dorsal gills on segment II (postsegmental position), segments III-VI (pre- \& postsegmental position) and segment VII (postsegmental position); ventral gills on segment II (postsegmental position), segments III-VI (pre- \& postsegmental position) and segment VII (postsegmental position); lateral gills absent; position of ventral gills shifted dorsad (Figs 20, 25). Lateral line from segment III-VIII; small bifurcated lamellae dorsal to lateral line present (Figs 20, 25; position of bifurcated lamellae highlighted in dashed ovals). Dorsal sclerite of segment IX semicircular, pale brown, with 4 pairs of setae (outermost lateral and medial setae very long, with interspersed shorter setae) (Fig. 22); anal proleg present, of limnephilid type (Fig. 23).

Case. Larval case 9.0-10.5 mm long, constructed from rectangular pieces of plant material; pieces subrectangular to quadratic, parts of barks or leaves; cross-section subrectangular to subquadrangular, tapering towards the posterior end (Fig. 24). 

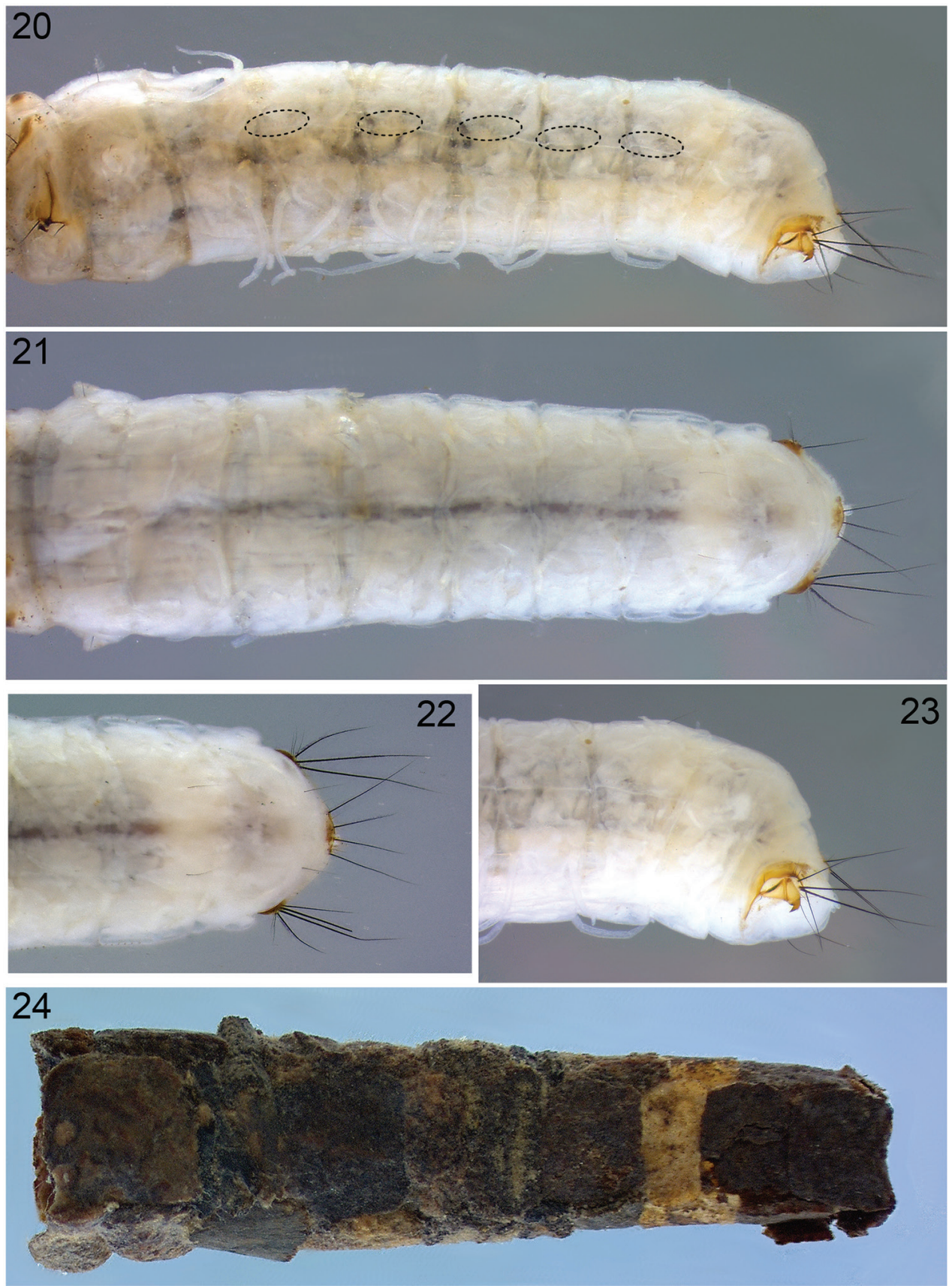

Figures 20-24. Lepidostoma scotti, $5^{\text {th }}$ instar larva. 20 Abdomen, segments I-X, lateral view (dashed ovals indicate position of forked lamellae), $13 \times \mathbf{2} \mathbf{I}$ Abdomen, segment I-X, dorsal, $13 \times \mathbf{2 2}$ Abdominal segment VII-X, dorsal, 25× 23 Abdomen, segment VII-X, lateral, 25×; 24 Larval case, left lateral view, 10×. 


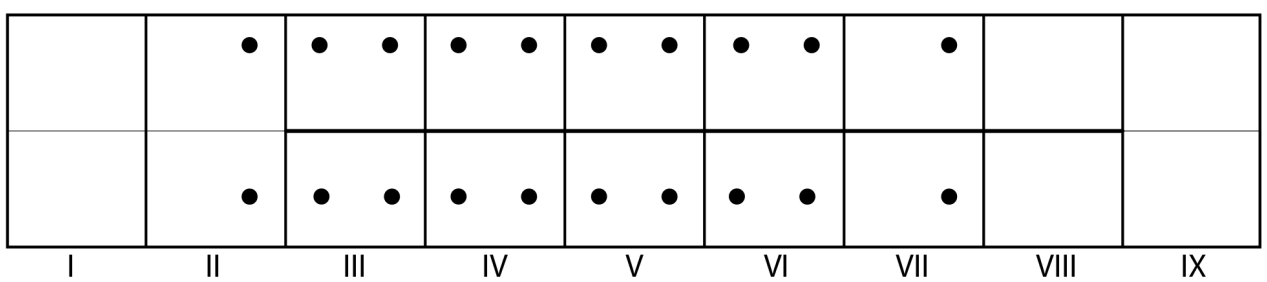

Figure 25. Lepidostoma scotti, $5^{\text {th }}$ instar larva. Gill diagram indicating position of dorsal and ventral gills and extent of lateral line (bold line). Lateral gills absent.

\section{Discussion}

Historically, the most comprehensive faunistic African studies were done in South Africa, Madagascar and West Africa. These studies yielded hundreds of Trichoptera species to the Afrotropical region, of which 253 species are known from South Africa (de Moor and Day 2013), more than 500 species from Madagascar (Benstead et al. 2003), and 343 species were reported from the West Africa region (Tobias and Tobias 2008). However, other regions of the African continent are not as well represented in the available caddisfly literature. In Ethiopia, 85 species are known currently, and the discovery of several new species within the next decades is likely. Particularly, on-going projects on water resource management and capacity building will foster faunistic surveys and thus provide highly relevant baseline data for both taxonomy and ecosystem monitoring.

However, most of the data available on diversity of the African Trichoptera fauna were compiled based on adult specimens, and most species are not known in the larval stage. According to Scott (1986) only 105 of 747 Sub-Saharan species of African Trichoptera were known in the larval stage at that time. Thus, development of more precise biomonitoring tools is severely hampered. Moreover, description of these larval stages could foster development of taxonomic expertise as crucially needed for biomonitoring and sustainable development of freshwater resources in the Afrotropical region. Consequently, faunistic surveys and taxonomic treatment of yet undescribed larval stages are of great value for the development of knowledge and human resources as well as for the documentation of freshwater biodiversity.

In general, larvae of the genus Lepidostoma inhabit springs and cool streams that usually have slow water flow and substantial input of allochthonous organic material (Wiggins 2004). Indeed, it is evident from the mandibles of L. scotti larvae (Fig. 13) that this species is, like most Lepidostoma, a detritivorous shredder that feeds on leaf litter and decaying woody debris. Moreover, larvae of Lepidostoma are known to exploit even recalcitrant resources, including the leaves of coniferous plants (Grafius and Anderson 1980; Wiggins 2004). The riparian zone of Chilimo Forest streams is usually dominated by the coniferous plants Juniperus procera and Podocarpus falcatus (Kassa et al. 2009; Teshome and Ensermu 2013). The leaves of these species most likely represent the primary food source of $L$. scotti larvae in these habitats. Other studies in 
Ethiopia indicated that Lepidostoma larvae exclusively live in forested streams instead of areas with intensified land use (Aschalew 2015; Ferengi 2016).

Larvae of the genus Oecetis are found in a wide range of freshwater habitats and are either carnivorous, or behave as detritivores or shredders (e.g., Waringer and Graf 2011). Larvae of carnivorous Oecetis species have elongated single-blade mandibles (Waringer and Graf 2011). Based on the elongated bladelike mandibles observed in O. mizrain, larvae of this species (Fig. 2) most likely have a predatory feeding behavior.

In addition to information on feeding ecology, stream zonation preference, sensitivity to organic pollution, or sediment load, knowledge on the flight periodicity of potential bioindicators is crucial to determine sampling seasons for biomonitoring approaches. According to Wright et al. (2013), caddisfly flight periodicity is likely controlled by a combination of innate behavior and environmental factors, most notably temperature. However, despite repeated sampling efforts in Ethiopia, the flight periods of single species could not yet be defined. Recent collections of adult $L$. scotti and O. mizrain revealed that these species were active in October and November (Malicky and Graf 2012, 2015), but their complete flight period remains unclear due to the lack of consistent faunistic surveys. In the eastern Afrotropical Region, these months are considered as the regeneration period for most macroinvertebrates following the heavy rainfall and high flooding season that extends from late June to mid-September (Aschalew 2015). However, flight periodicity of any Ethiopian caddisfly taxa has yet to be studied throughout the year, and further investigations on the annual flight period are currently under way.

Caddisfly larvae are widely used as indicator taxa in freshwater assessments as they exploit a wide range of ecological niches, often are found in abundance and cover a wide sensitivity range (Aschalew and Moog 2015; Barbour et al. 1999; Chakona et al. 2009; Hering et al. 2003). Ideally, assessment of the ecological condition of aquatic ecosystems is based on the identification of macroinvertebrates to species-level (Sharma et al. 2008). Jones (2007) also emphasizes the importance of species datasets for a better interpretation of bioassessment results, as well as testing ecological theories and evaluating threats of extinction to aquatic taxa. In particular, lack of species-level information leads to underestimating the actual differences in community structure (Benstead et al. 2003). Therefore, species-level resolution is fundamental for freshwater biomonitoring (Lenat and Resh 2001; Malicky et al. 2008; Corbi and Trivinho-Strixino 2006).

To achieve a better understanding of Ethiopian freshwater biodiversity and the biogeography of African freshwater fauna in general, description of species and preparation of species-level keys is imperative. Here we provide some data that might be useful for future studies to characterize the Ethiopian caddisfly fauna.

\section{Acknowledgement}

We are most grateful to Hans Malicky for confirming identification results. Fieldwork was conducted under the auspices of the LARIMA - Sustainable HighLAnd RIvers 
MAnagement in Ethiopia - project (Project Number 106) funded by the Austrian Partnership Programme in Higher Education and Research for Development (APPEAR) of the Austrian Development Cooperation (ADC) and the Austrian Agency for International Cooperation in Education and Research (OeAD).

\section{References}

Abell R, Thieme ML, Revenga C, Bryer M, Kottelat M, Bogutskaya N, Coad B, Mandrak N, Balderas SC, Bussing W, Stiassny ML, Skelton P, Allen GR, Unmack P, Naseka A, Ng R, Sindorf N, Robertson J, Armijo E, Higgins JV, Heibel TJ, Wikramanayake E, Olson D, López HL, Reis RE, Lundberg JG, Sabaj Pérez MH, Petry P (2008) Freshwater ecoregions of the world: a new map of biogeographic units for freshwater biodiversity conservation. BioScience 58: 403-414. https://doi.org/10.1641/B580507

Aschalew L (2015) Assessing anthropogenic impacts using benthic macroinvertebrate as bioindicators in central highland streams of Ethiopia. Ethiopian Journal of Environmental Studies and Management 8: 45-56. https://doi.org/10.4314/ejesm.v8i1.5

Aschalew L, Moog O (2015) A multimetric index based on benthic macroinvertebrates for assessing the ecological status of streams and rivers in central and southeast highlands of Ethiopia. Hydrobiologia 751: 229-242. https://doi.org/10.1007/s10750-015-2189-1

Barbour MT, Gerritsen J, Snyder BD, Stribling JB (1999) Rapid bioassessment protocols for use in streams and wadeable rivers: periphyton, benthic macroinvertebrates and fish $\left(2^{\text {nd }} \mathrm{ed}.\right)$. Environmental Protection Agency, Office of Water, Washington, 339 pp.

Benstead J, De Rham P, Gattolliat J, Gibon F, Loiselle P, Sartori M, Sparks J, Stiassny M (2003) Conserving Madagascar's Freshwater Biodiversity. BioScience 53: 1101-1111. https://doi.org/10.1641/0006-3568(2003)053[1101:CMFB]2.0.CO;2

Brecko J, Mathys A, Dekoninck W, Leponce M, VandenSpiegel D, Semal P (2014) Focus stacking: Comparing commercial top-end set-ups with a semi-automatic low budget approach. A possible solution for mass digitization of type specimens. ZooKeys 464: 1-23. https://doi.org/10.3897/zookeys.464.8615

Cranston PS (1990) Biomonitoring and invertebrate taxonomy. Environmental Monitoring and Assessment 14: 265-273. https://doi.org/10.1007/BF00677921

Chakona A, Phiri C, Day JA (2009) Potential for Trichoptera communities as biological indicators of morphological degradation in riverine systems. Hydrobiologia 621: 155-167. https://doi.org/10.1007/s10750-008-9638-z

Corbi JJ, Trivinho-Strixino S (2006) Influence of taxonomic resolution of stream macroinvertebrate communities on the evaluation of different land uses. Acta Limnologica Brasiliensis 18: 469-475.

de Moor FC, Day JA (2013) Aquatic biodiversity in the mediterranean region of South Africa. Hydrobiologia 719: 237-268. https://doi.org/10.1007/s10750-013-1488-7

de Moor FC, Ivanov VD (2008) Global diversity of caddisflies (Trichoptera: Insecta) in freshwater. Hydrobiologia 595: 393-407. https://doi.org/10.1007/s10750-007-9113-2 
Ferengi BK (2016) Studies on spring and stream benthic macroinvertebrate communities in the upper Awash River at Chilimo, West Shoa Zone, Ethiopia. MSc Thesis, Ambo University, Ambo.

Grafius AE, Anderson NH (1980) Populations dynamics and role of two species of Lepidostoma (Trichoptera: Lepidostomatidae ) in an Oregon Coniferous Forest Stream. Ecology 61: 808-816. https://doi.org/10.2307/1936751

Hadley A (2008) CombineZP. http://www.hadleyweb.pwp.blueyonder.co.uk/CZP/News.htm [accessed 12 May 2012]

Hering D, Buffagni A, Moog O, Sandin L, Sommerhäuser M, Stubauer I, Feld C, Johnson R, Pinto P, Skoulikids N, Verdonschot P, Zahrádková S (2003) The development of a system to assess the ecological quality of streams based on macroinvertebrates - design of the sampling programme within the AQEM project. International Review of Hydrobiology 88: 345-361. https://doi.org/10.1002/iroh.200390030

Holzenthal RW, Thomson RE, Ríos-Touma B (2015) Order Trichoptera. In: Rogers DC (Ed.) Thorp and Covich's Freshwater Invertebrates ( $4^{\text {th }}$ edn). Academic Press, Boston, 965-1002. https://doi.org/10.1016/B978-0-12-385026-3.00038-3

Johanson KA (1992) A catalogue of the caddis flies of East Africa (Insecta, Trichoptera). Zoological Museum 18: 113-141.

Jones FC (2008) Taxonomic sufficiency: the influence of taxonomic resolution on freshwater bioassessments using benthic macroinvertebrates. Environmental Reviews 16: 45-69. https://doi.org/10.1139/A07-010

Kassa H, Campbell B, Sandewall M, Kebede M, Tesfaye Y, Dessie G, Seifu A, Tadesse M, Garedew E, Sandewall K (2009) Building future scenarios and uncovering persisting challenges of participatory forest management in Chilimo Forest, Central Ethiopia. Journal of environmental management 90: 1004-1013. https://doi.org/10.1016/j.jenvman.2008.03.009

Kimmins DE (1963) On the Trichoptera of Ethiopia. Bulletin of the British Museum (Natural History) Entomology 13: 119-170.

Lenat DR, Resh VH (2001) Taxonomy and stream ecology - The benefits of genus- and specieslevel identifications. Journal of the North American Benthological Society 20: 287-298. https://doi.org/10.2307/1468323

Malicky H, Graf W (2012) Eine kleine Trichopterenausbeute aus Äthiopien. Braueria 39: 32-38.

Malicky H, Graf W (2015) Einige neue afrikanische Köcherfliegen (Trichoptera). Braueria 42: 31-35.

Malicky H, Karma G, Moog O (2008) A survey of the caddisflies (Insecta, Trichoptera) of Bhutan, with suggestions for further research. In: Moog O, Hering D, Sharma S, Stubauer I, Korte T (Eds) ASSESS-HKH: Proceedings of the Scientific Conference "Rivers in the Hindu Kush-Himalaya - Ecology \& Environmental Assessment”. Nepal, 91-95.

Morse JC (2011) Trichoptera World Checklist. Zoosymposia 5: 372-380.

Morse JC [Ed.] (2017) Trichoptera World Checklist. http://www.entweb.clemson.edu/database/trichopt/index.htm [Accessed 10 April 2017]

Sharma S, Bajracharya RM, Nesemann H, Tachamo RD, Shah DN, Timalsina S (2008) Results and consequences of the ASSESS-HKH Research Project in Nepal. In: Moog O, Her- 
ing D, Sharma S, Stubauer I, Korte T (Eds) ASSESS-HKH: Proceedings of the Scientific Conference "Rivers in the Hindu Kush-Himalaya - Ecology \& Environmental Assessment”. Nepal, 55-63.

Schmidt-Kloiber A, Graf W, Lorenz A, Moog O (2006) The AQEM/STAR taxalist - a panEuropean macro-invertebrate ecological database and taxa inventory. Hydrobiologia 566: 325-342. https://doi.org/10.1007/s10750-006-0086-3

Scott KMF (1986) A brief conspectus of the Trichoptera (Caddisflies) of the Afrotropical Region. Journal of the Entomological Society of South Africa 49: 231-238.

Teshome S, Ensermu K (2013) Diversity and endemicity of Chilimo forest, central Ethiopia. Bioscience Discovery 4: 1-4.

Tobias D, Tobias W (2008) Trichoptera africana. http://www.trichoptera.insects-online.de/ Trichoptera\%20africana/index.htm [accessed 16 November 2017]

Ulmer G (1930) XLIX.-Entomological expedition to Abyssinia, 1926-27; Trichoptera and Ephemeroptera. Annals and Magazine of Natural History 6: 479-511. https://doi. org/10.1080/00222933008673238

Waringer J, Graf W (2011) Atlas of Central European Trichoptera Larvae. Erik Mauch Verlag, Dinkelscherben, 468 pp.

Wright DR, Pytel AJ, Houghton DC (2013) Nocturnal flight periodicity of the caddisflies (Insecta: Trichoptera) in a large Michigan river. Journal of freshwater ecology 28: 463-476. https://doi.org/10.1080/02705060.2013.780187

Wiggins GB (1996) Larvae of the North American Caddisfly Genera (Trichoptera) (2 ${ }^{\text {nd }}$ end). University of Toronto Press, Toronto.

Wiggins GB (2004) Caddisflies: the underwater architects. University of Toronto Press, Totonto, 292pp. 